\title{
Are There Any Differences in the Neural and Extracellular Matrix Proteins Density Between Children and Adults with Intrinsic Ureteropelvic Junction Obstruction?
}

\author{
Çocuk ve Erişkin Üreteropelvik Bileşke Darlı̆̆ında Nöral ve Ekstraselüler Matriks Proteinleri \\ Arasında Farkılık Var mı?
}

Bahadır Şahin1, Cevdet Kaya1, Farhad Talibzade1, Yılören Tanıdır1, Feriha Ercan², Elif Kervancıoğlu Demirci², Çağrı Akın Şekerci¹, Cem Akbal1, Ferruh Şimşek1

${ }^{1}$ Marmara University Faculty of Medicine, Department of Urology, Istanbul, Turkiye

2 Marmara University Faculty of Medicine, Department of Histology-Embryology, Istanbul, Turkiye

What's known on the subject? and What does the study add?

There are lots of studies on the histology of the obstructed segment of UPO patients. Although there are some conflicting results, most of the studies performed to date state that while muscle and neural tissue decrease in UPO, connective tissue and extracellular matrix proteins increase. All these studies have been conducted whether on children or adults. This is the first study that compared the specimens from adult and child population. Our study will help us better understand the progression of ureteropelvic junction obstruction throughout life and create a better understanding on the timing and need of surgery.

\begin{abstract}
Objective: To compare changes in connective, neural and muscle tissues, and extracellular matrix in child and adult patients so that we can create a more objective view on the timing of surgery.

Materials and Methods: Twenty-six patients, who were operated for ureteropelvic junction (UPJ) obstruction in our clinic between September 2014 and May 2016, were included in the study. For the evaluation of connective tissue, Masson's trichrome staining was used. Muscle, extracellular matrix elements and neural tissue were evaluated with immunohistochemistry using alpha-smooth muscle actin ( $\alpha-S M A)$, Tenascin C and S100, respectively. Microscopically, the tissues were scored according to their staining density (0: No staining; 1: Minor; 2: Moderate, 3: Dense).

Results: There were 12 children and 14 adults in the study groups. The initial evaluation showed no statistically significant difference between studied tissue types with respect to staining density for all parameters (Masson: $p=0.414, \alpha-S M A: p=0.204$, Tenascin-C: $p=0.264, S 100: p=0.534$ ).

There was no statistically significant correlation between staining density and renal function percentage of the affected kidney (Masson: $r=0.454$, $p=0.051-\alpha-S M A: r=-0.323, p=0.177-$ Tenascin- $: r=0.290, p=0.229-S 100: r=-0.080, p=0.744)$.

Conclusion: Our preliminary study showed some structural changes between adult and child patients but there is no statistically significant difference between the groups with respect to staining density scores. These results state that although UPJ obstruction is an ongoing process, there is no correlation between the histological deterioration degree of the UPJ segment and the loss on renal function for both children and adults. Keywords: Extracellular matrix, immunohistochemistry, muscle tissue, connective tissue, neural tissue, ureteropelvic junction
\end{abstract}

Öz

Amaç: Cerrahi zamanlaması üzerine daha objektif bir görüş oluşturabilmek için çocuk ve erişkin hastaların bağ, sinir, kas dokuları ve ekstraselüler matriks proteinlerindeki değişiklikleri karşılaştırmaktır.

Gereç ve Yöntem: Kliniğimizde Eylül 2014-Mayıs 2016 tarihleri arasında üreteropelvik bileşke (UPB) darlığı nedeniyle opere edilen 26 hasta çalışmaya dahil edildi. Bağ dokusu değerlendirmesi için Masson trikrom boyama kullanıldı. Kas, ekstraselüler matriks elemanları ve sinir dokusu

Correspondence: Bahadır Şahin MD, Marmara University Faculty of Medicine, Department of Urology, İstanbul, Turkiye Phone: +90 2166254545 E-mail: drbahadirsahin@gmail.com ORCID ID: orcid.org/0000-0002-4874-4178

Received: 22.09 .2017 Accepted: 23.09 .2017

Cite this article as: Şahin B, Kaya C, Talibzade F, Tanıdır Y, Ercan F, Kervancıoğlu Demirci E, Şekerci ÇA, Akbal C, Şimşek F. Are There Any Differences in the Neural and Extracellular Matrix Proteins Density Between Children and Adults with Intrinsic Ureteropelvic Junction Obstruction? J Urol Surg 2017;4:177-182. 
sırasıyla alfa smooth-muscle aktin ( $\alpha$-SMA), Tenascin C ve S100 kullanılarak immünhistokimyasal olarak değerlendirildi. Mikroskopik dokular boyama yoğunluğuna göre skorlandı (0: Boyanma yok, 1: Minör, 2: Orta, 3: Yoğun).

Bulgular: Çalışma grubunda 12 çocuk ve 14 yetişkin vardı. İlk değerlendirme, incelenen doku tiplerinde, tüm parametreler için boyama yoğunluğuna göre istatistiksel olarak anlamlı bir fark olmadığını gösterdi (Masson: $p=0,414, \alpha$-SMA: $p=0,204$, Tenascin-C: $p=0,264, S 100$ : $p=0,534$ ). Etkilenen böbreklerin boyanma yoğunluğu ile renal fonksiyon yüzdesi arasında istatistiksel olarak anlamlı bir korelasyon yoktu (Tenascin-C: $r=0,290, p=0,229$ - S100: $r=-0,080, p=0,744)$.

Sonuç: Çalışmamız yetişkin ve çocuk hastalar arasında bazı yapısal değişiklikler olduğunu göstermiş ancak boyama yoğunluğu puanlarında gruplar arasında istatistiksel olarak anlamlı bir fark bulunamamıştır. Bu sonuçlar, UPB darlığının devam eden bir süreç olduğunu göstermekle birlikte, UPB segmentinin histolojik bozulma derecesi ile hem çocuklarda hem de erişkinlerde böbrek fonksiyonlarındaki kayıp arasında bir korelasyon olmadığını ortaya koymaktadır.

Anahtar Kelimeler: Ekstraselüler matriks, immünhistokimya, kas dokusu, bağ dokusu, sinir dokusu, üreteropelvik bileşke

\section{Introduction}

Ureteropelvic junction (UPJ) obstruction (UPJO), which is defined as impairment in the urine passage from the renal pelvis to ureters, is the leading underlying pathological condition in antenatal hydronephrosis (1). Although UPJO can be diagnosed at any age, developments on fetal screening studies such as ultrasound led to diagnosis of this condition as early as antenatal life.

The underlying pathophysiological mechanisms of UPJO have been investigated in many studies. Anomalies in muscle tissue of the renal pelvis and ureter are the most commonly suggested factors playing a role in the development of UPJO (2). Some studies also show that abnormal neural stimulation and structural defects in collagen can also have a role in the development of the disease. There are conflicting results in studies on the effect of the distribution of neural tissue and extracellular matrix (ECM) in UPJO. In a recent study, it has been showed that in children with intrinsic UPJO, there was increased expression of collagen fibers and ECM; whereas a marked decrease in the density of muscle and neural tissues were observed (3).

In recent years, the increased number of early-diagnosed UPJO cases has led to the question about timing of surgery. Current approach to UPJO is based on functional studies. Our lack of knowledge on the developmental process of the disease makes it impossible to establish treatment strategies based on pathophysiology. Although most cases of UPJO are followed without any interventions up to adult life, there are limited data on the course and long-term histological changes of the disease.

This preliminary study aims to investigate changes in UPJ with respect to muscle, connective tissue, ECM and neural tissues between pediatric and adult patients. To our knowledge, our study is the first study assessing histological changes in children and adult populations. Our results may help obtain a clearer picture about pathophysiological development of UPJO and help us develop more objective treatment strategies based on pathophysiology.

\section{Materials and Methods}

Thirty patients who were operated for UPJO in our clinic between September 2014 and May 2016 were selected for the study. Four cases whose UPJO was caused by extrinsic etiologies like crossing vessels were excluded and final analysis was conducted on the remaining 26 intrinsic UPJO patients. The patients were grouped as adults and children with respect to their age; patients younger than 18 years of age were defined as children.

\section{Exclusion Criteria}

In all UPJO cases, the diagnosis was confirmed with radiologic and scintigraphic methods before the surgery. Ureteropelvic obstruction cases with renal stone in the affected side or with vesicoureteral reflux were not included in the study. In case of uncertainty in the diagnosis, cases were evaluated with retrograde pyelography to confirm UPJO. In two patients, laparoscopic simple nephrectomy was performed for recurrent febrile urinary tract infections. The remaining patients underwent Anderson-Hynes pyeloplasty. All pyeloplasty cases were planned as laparoscopic surgery.

\section{Surgical Selection}

Patients, whose renal function was recorded to be less than $40 \%$ on the affected side at the time of diagnosis, who had a decline in renal function for more than $10 \%$ in consecutive scans, who had a completely obstructed UPJ even after diuretic admission in nuclear renogram, and patients whose affected kidney showed an increase in anterior-posterior pelvis diameter in consecutive scan, were recommended for pyeloplasty according to the European Association of Urology Guidelines.

\section{Immunohistochemistry}

After the UPJ segments excised during the pyeloplasty were fixated in $4 \%$ formaldehyde with neutral buffering, they were 
embedded in paraffin blocks for preservation until histological evaluation. These paraffin blocks were cut with microtome blade into 5-micrometer sections and after complete removal of paraffin from the samples, 4 types of staining were chosen to evaluate the samples.

All staining procedures were conducted in histology and embryology laboratory in our institute. For the evaluation of connective tissue, Masson's trichrome staining (Sigma Aldrich HT15-1KT) was performed. Muscle density, neural structure and ECM elements were evaluated immunohistochemically. For these purposes, alpha-smooth muscle actin ( $\alpha$-SMA), Tenascin C (TNC) and S-100 were chosen as markers.

Expose Mouse and Rabbit Specific HRP/DAB Detection IHC kit (Abcam, ab804436) was used according to the instructions provided by the manufacturer on all slides. After passing through alcohol series, the slides were blocked with hydrogen peroxide for 10 minutes. Then, the slides were washed with phosphate buffer solution (PBS) (Biomatik, A3602) twice. For $\alpha-S M A$, no antigen exposure was performed. Citrate buffer (Bio-Optica, 15M103) was used for antigen exposure in TNC and S-100 staining procedures and the slides were washed with PBS three times. In order to block non-specific background staining, protein block was performed in room temperature for 10 minutes. After protein block, monoclonal antibodies which were $\alpha$-SMA (Abcam, 7817,1:400, 1 hour incubation in room temperature), TNC (Santa Cruz, SC25328, 1:50, 1 night incubation in $+4{ }^{\circ} \mathrm{C}$ ) and S-100 (Santa Cruz, SC53438, 1:50, 1 hour incubation in room temperature) were used. The slides were washed with PBS three more times. After this, HRP conjugate was dropped for 15 minutes in room temperature and the slides were washed with PBS 4 times. Next, DAB solution was dropped and the slides washed with PBS four more times. Staining of nucleus was performed with Mayer's hematoxylin.

\section{Evaluation and Scoring}

All slides were observed with light microscope (Olympus BX51i Tokyo, Japan) by two independent observers and for each staining, a semi-quantitative scoring was performed. With respect to staining densities, the slides were scored between 0 and 3 (0: No staining, 1: Mild, 2: Moderate, 3: Dense). For determination of staining density of S-100 protein, 5 random areas with resemblance were chosen and with respect to staining density, 0 was scored in case of 1-3 positive staining, 1 was scored in case of 4-8 positive staining and 3 was scored in case of 9 or more positive staining.

\section{Statistical Analysis}

Statistical analyses were performed using the original SPSS software, version 22.0 (IBM Corp, NY, USA), with significance set at $p<0.05$. Baseline variables were described using means and standard deviations, or medians and 25th and $75^{\text {th }}$ percentile values as appropriate. The Mann-Whitney $\mathrm{U}$ test was used to evaluate the difference between quantitative measurements that does not have normal distribution. Chi-square test was applied to evaluate categorical data and the two-sided $p$ value was used in inference. Correlation between two quantitative variables was evaluated with Spearman's correlation coefficient. Confidence intervals were set at 95\% before performing all tests.

This study was approved by the Ethics Committee of Marmara University Faculty of Medicine (approval number: 09.2015.070) and conducted with the guidance of the declaration of Helsinki. Informed consents were taken from all the participating patients. The financial support for this study was provided by Marmara University Scientific Research Projects Commission.

\section{Results}

Of 26 patients included in the study, 12 were in pediatric age group and 14 were in adult age group. Median patient age for all groups was 19.5 (5-30) years. Median age was 63.5 (13-127) months in children and 26.5 (22-39) years in adults. There was no statistically significant difference between groups with respect to gender distribution and laterality of the disease (Table 1).

All patients who underwent laparoscopic pyeloplasty were evaluated either with mercaptoacetyltriglycine or diethylenetriaminepentaacetate scintigraphy. All renograms showed obstructive pattern in all patients with no response to diuretic admission. The median calculated split renal functions were $44.5(37.0-51.0)$ and 47.35 (43.5-50.0) in children and adults, respectively. There was no statistically significant difference between the groups with respect to measured renal function percentage ( $p=0.436)$.

In tissue slides with Masson's trichrome staining, the collagen fibers were observed as blue stained and muscle tissue elements were seen as pink-red stained. Histologically; in the slides of adult patients, it has been observed that connective tissue was increased in submucosal area, muscular and adventitia layers, whereas muscular tissue was observed to be decreased in these

Table 1. Comparison of descriptive variables among patient groups

\begin{tabular}{lllll}
\hline \multicolumn{4}{c}{ Patient group } \\
\hline \multirow{4}{*}{ Gender } & Children $(\mathrm{n}=12)$ & \multicolumn{2}{c}{ Adults $(\mathrm{n}=12)$} & $\mathbf{p}$ \\
& Male $(\mathrm{n}=18)$ & $9(50 \%)$ & $9(50 \%)$ & \\
& Female $(\mathrm{n}=8)$ & $3(37.3 \%)$ & $5(62.5 \%)$ & $0.555^{1}$ \\
\multirow{4}{*}{ Laterality } & Right $(\mathrm{n}=10)$ & $5(50 \%)$ & $5(50 \%)$ & \\
& Left $(\mathrm{n}=16)$ & $7(43.8 \%)$ & $9(56.3 \%)$ & $0.756^{1}$ \\
\hline 1Chi-square test & & &
\end{tabular}


areas. On the contrary, on the slides of children, decreased connective tissue and increased muscle tissue elements were observed microscopically. Although histologically structural changes were observed, there were no statistically significant difference with respect to staining density scores between the groups $(p=0.414)$.

On slides evaluated with immunohistochemistry; positive stained antibodies of $\alpha$-SMA, TNC and S-100 were observed as brown areas whereas other tissue elements were seen in light blue color (Figure 1, 2).

Although it was microscopically observed that muscle tissue on adult slides seemed to be decreased and thinned, there was no statistically significant difference between adult and children tissues with respect to $\alpha$-SMA staining density scores $(p=0.204)$. When the two groups were compared with respect to TNC staining density scores, $25.0 \%$ of adult patient slides were scored

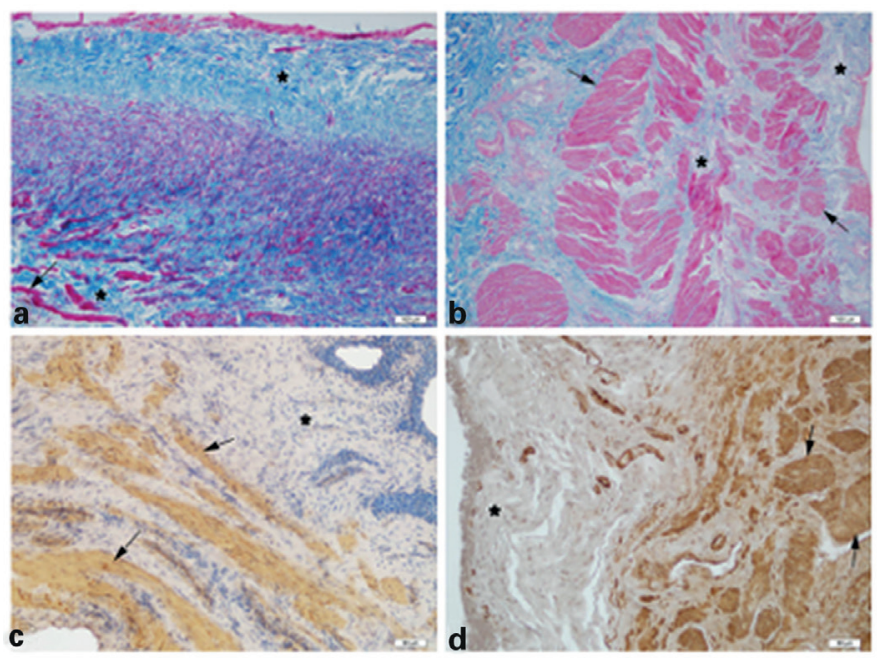

Figure 1. Trichrome staining of masson in an adult (a) and child (b) \& alpha smooth muscle actin immunohystochemical staining in an adult (c) and child (d)

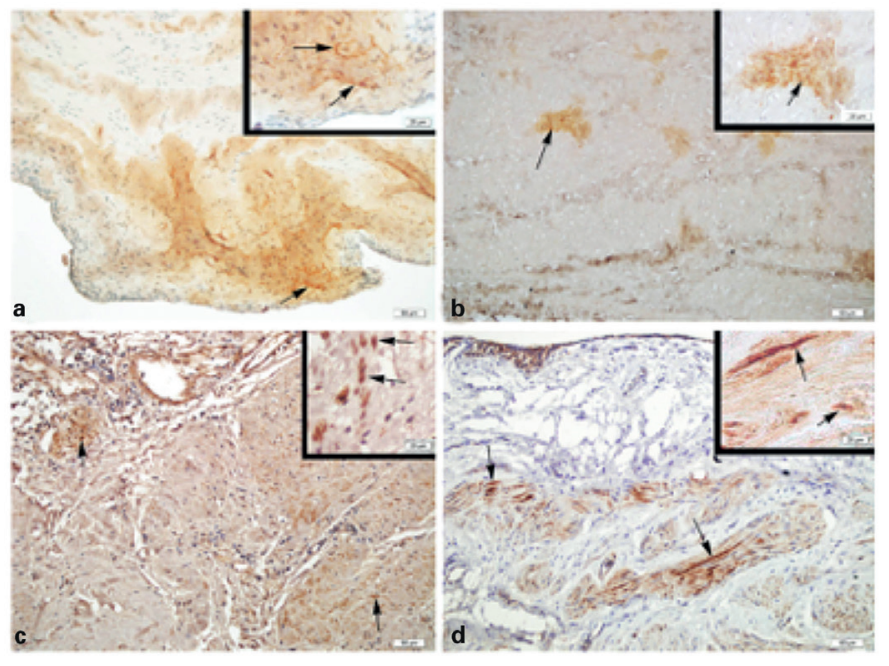

Figure 2. Tenascin $\mathrm{C}$ immunohistochemical staining in an adult (a) and child (b) \& S-100 immunohistochemical staining in an adult (c) and child (d) as dense stained whereas only $8.3 \%$ of child slides were scored as dense. Although this difference was also observed under the microscope, the difference was not statistically significant $(p=0.264)$. Comparison of neural tissue with the use of S-100 showed no difference between groups both microscopically and with respect to staining density scores. The rate of dense stained slides was $16.7 \%$ in children and $8.3 \%$ in adults in S-100 staining $(p=0.534)$.

There was no statistically significant correlation between all the 4 staining scores and anterior-posterior renal pelvis diameter of patients measured preoperatively. The measured renal function percentage was as also not correlated with staining density for all the 4 tissues (Table 2).

There was also a strong correlation between the staining densities of $\alpha$-SMA and S-100 proteins in pediatric patient group $\left(r_{s}=0.889-p<0.001\right)$. This correlation could not be observed in adult patient group $\left(r_{s}=0.149-p=0.612\right)$. Other staining parameters were not correlated in all patient groups.

Table 2. Correlation between staining densities and radiologic parameters

\begin{tabular}{lllll}
\hline & Masson & $\alpha-S M A$ & TNC & $\mathrm{S}-100$ \\
\hline \multirow{2}{*}{ APPD } & $r_{s}=0.250$, & $r_{s}=-0.107$, & $r_{s}=0.168$, & $r_{s}=0.127$, \\
& $p=0.333$ & $p=0.684$ & $p=0.518$ & $p=0.628$ \\
Renal function (\%) & $r_{s}=0.454$, & $r_{s}=0.323$, & $r_{s}=0.290$, & $r_{s}=0.080$ \\
& $p=0.0 .51$ & $p=0.177$ & $p=0.229$ & $p=0.744$ \\
\hline
\end{tabular}

$\alpha$-SMA: Alpha smooth muscle actin, TNC: Tenascin C, APPD: Anterior posterior pelvis diameter, $r_{s}=$ Spearmen correlation coefficient

\section{Discussion}

Studies on the pathophysiology of UPJO usually concentrate on the muscle tissue changes, ECM elements, connective tissue and neural structures of the obstructed segment. Kaya et al. (3) showed that in children with UPJO, smooth muscle elements and neural tissue decreased in UPJ segment whereas ECM and connective tissue increased. To our knowledge, this is the first study comparing child and adult UPJ tissues.

There are other studies demonstrating the effect of abnormal neural structures in UPJO. In their study, Wang et al. (4) demonstrated decreased nerve growth factor mRNA in UPJO tissue. The close relationship of apoptosis in the muscle tissue as a result of impairments in the neural stimulus is also shown in the same study. The correlation between decrease in neural tissue and increase in apoptosis index of muscle tissue is also demonstrated in another study (5). Although the correlation between neural and muscle tissues is well demonstrated, it is still unclear whether the decrease in neural stimulus causes muscle atrophy or muscle atrophy itself causes neural denervation. This relationship was also observed in our study in pediatric patient group. In our study, histologically, the 
structures of neural elements showed similar characteristics in children and adult patient groups, and given that there was no statistically significant difference between the groups with respect to staining density scores, it can be presumed that in the pathophysiological process of UPJO, neural tissue disorders remain in a stable course. On the other hand, in the analysis of $\alpha-S M A$, the average score of the pediatric patient group was higher than that of the adult group and the microscopic images of the two groups showed that the muscle fibers observed in the pediatric patient group were more regular and thicker. This suggests that the pathology due to UPJO may be in an advancing fashion for the muscle tissue.

Tenascins are a family of glycoproteins that have four different types affecting the structure of ECM and the physiology of ECMassociated cells. TNC is mostly involved in smooth muscle (6). This glycoprotein is effective particularly during organogenesis. In organs that completed their development; it can either be in very small amounts or not be found. However, in pathological conditions such as infection, inflammatory conditions or tumor growth, the efficacy and quantity of the TNC increase in the tissue. In fully developed organs, TNC plays a role in the development of fibrosis, ECM secretion and cell proliferation (7). In a study conducted in pediatric patient group, it has been shown that an increase in TNC may have an important role in deterioration of muscle tissue in ureterovesical junction of patients with vesicoureteral reflux (8). Similarly, an increase in TNC levels has been reported in children with UPJO compared to that in controls (3). In our study, even if not statistically significant, increased TNC concentration in the adult patient group, especially in muscle and connective tissues, demonstrates that UPJO is not a static process with regard to structure and turn-over of ECM products.

In a study comparing the results of preoperative renal nuclear scintigraphy with histological changes in kidney biopsy taken during the operation, it was observed that in $25 \%$ of pediatric patients with UPJO, there was inconsistency between renal biopsy and renal scintigraphic results (9). Also Zhang et al. (10) showed that the samples taken from the UPJ segment in pyeloplasty only correlated with renal function percentage if there was severe fibrosis in the UPJ. Consistent with these results, our study demonstrated that there was no correlation between deterioration of UPJ segment and scintigraphic renal function percentage. With these results, it can be interpreted that the radiologic and nuclear imaging modalities lack to demonstrate molecular changes in the course of UPJO.

In recent years, with the use of prenatal screening tests; UPJO has started to be diagnosed earlier. This situation complicated the decision of the surgeon with regard to the timing of treatment. A study in which patients with grade 3 hydronephrosis according to the Society of Fetal Urology criteria were randomized to follow-up and surgical treatment arms in the antenatal period; $25 \%$ of patients in the follow-up arm developed surgical need within 3 years after randomization (11). Likewise there are other studies which shows better recovery in renal functions after early repair of UPJO $(12,13)$. Nevertheless, in a study which evaluated kidney function after pyeloplasty in pediatric patient group, functional improvement was reported after treatment regardless of age (14). Contrary to these results, there are other studies questioning the benefit of early repair in UPJO $(15,16)$.

\section{Study Limitations}

Our study has some limitations such as lack of a control group for comparison. This is mainly due to the fact that the aim of this study was to compare adult and children patient populations. The changes in children are well documented by previous studies but difference between children and adults have not been reported. On the other hand, although most of the studies on UPJO were conducted with almost the same number of patients with our study, it is clear that with greater number of patients the difference between groups could reach to a statistically significant level. Studies with larger sample would help us differentiate the pathophysiological changes between children and adults.

\section{Conclusion}

The timing of surgery is still a matter of debate with the conflicting evidence in the literature. Understanding the pathophysiology and progress of the disease has an utmost importance in decision-making for treatment. Given the results in our study, it can be said that although some structures like muscle seem to deteriorate over time, there is no statistically significant difference between child and adult UPJ segments with respect to staining densities of connective, muscle, neural tissues and ECM components. Although this may indicate that patients would not get any additional benefit from treatment with early surgery instead of waiting until a functional impairment; it is clear that imaging studies do not always demonstrate the actual damage. In the future studies on the markers that may have potential to show early renal damage will be of utmost importance for decision making for the timing of UPJ surgery.

\section{Ethics}

Ethics Committee Approval: This study was approved by Ethics Committee of Marmara University Faculty of Medicine (approval number: 09.2015.070).

Informed Consent: Consent form was filled out by all participants.

Peer-review: Internally peer-reviewed. 


\section{Authorship Contributions}

Surgical and Medical Practices: C.K., C.A., Y.T., Ç.A.Ş., Concept: B.Ş., C.K., F.Ş., Design: B.Ş., C.K., F.T., Data Collection or Processing: B.Ş., Y.T., Ç.A.Ş., Analysis or Interpretation: B.Ş., F.E., E.K.D., Literature Search: B.Ş., Writing: B.Ş., C.K.

Conflict of Interest: No conflict of interest was declared by the authors.

Financial Disclosure: The financial support for this study was provided by Marmara University Scientific Research Projects Commission (BAPKO).

\section{References}

1. Nguyen $H T$, Herndon CA, Cooper C, Gatti J, Kirsch A, Kokorowski P, Lee $R$, Perez-Brayfield M, Metcalfe P, Yerkes E, Cendron M, Campbell JB. The Society for Fetal Urology consensus statement on the evaluation and management of antenatal hydronephrosis. J Pediatr Urol 2010;6:212-231.

2. Klein J, Bascands JL, Mischak H, Schanstra JP. The role of urinary peptidomics in kidney disease research. Kidney Int 2016;89:539-545.

3. Kaya C, Bogaert G, de Ridder D, Schwentner C, Fritsch H, Oswald J, Radmayr C. Extracellular matrix degradation and reduced neural density in children with intrinsic ureteropelvic junction obstruction. Urology 2010;76:185-189.

4. Wang Y, Puri P, Hassan J, Miyakita H, Reen D. Abnormal innervation and altered nerve growth factor messenger ribonucleic acid expression in ureteropelvic junction obstruction. J Urol 1995;154:679-683.

5. Kajbafzadeh AM, Payabvash $\mathrm{S}$, Salmasi AH, Monajemzadeh M, Tavangar SM. Smooth muscle cell apoptosis and defective neural development in congenital ureteropelvic junction obstruction. J Urol 2006;176:718-723.
6. Chiquet-Ehrismann R, Tucker RP. Connective tissues: signalling by tenascins. Int J Biochem Cell Biol 2004;36:1085-1089.

7. Chiquet-Ehrismann R, Chiquet M. Tenascins: regulation and putative functions during pathological stress. J Pathol 2003;200:488-499.

8. Schwentner C, Oswald J, Lunacek A, Pelzer AE, Fritsch H, Schlenck B, Karatzas A, Bartsch G, Radmayr C. Extracellular microenvironment and cytokine profile of the ureterovesical junction in children with vesicoureteral reflux. J Urol 2008;180:694-700.

9. Elder JS, Stansbrey R, Dahms BB, Selzman AA. Renal histological changes secondary to ureteropelvic junction obstruction. J Urol 1995;154:719-722.

10. Zhang PL, Peters $C A$, Rosen S. Ureteropelvic junction obstruction: morphological and clinical studies. Pediatr Nephrol 2000;14:820-826.

11. Palmer LS, Maizels M, Cartwright PC, Fernbach SK, Conway JJ. Surgery versus observation for managing obstructive grade 3 to 4 unilateral hydronephrosis: a report from the Society for Fetal Urology. J Urol 1998;159:222-228.

12. Chertin B, Fridmans A, Knizhnik M, Hadas-Shalperin I, Hain D, Farkas A. Does early detection of ureteropelvic junction obstruction improve surgical outcome in terms of renal function? J Urol 1999;162:1037-1040.

13. Mikkelsen $S$, Rasmussen $B$, Jensen $T$, Hanghøj-Petersen W, Christensen PO. Long-term Follow-up of Patients with Hydronephrosis Treated by AndersonHynes Pyeloplasty. Br J Urol 1992;70:121-124.

14. Salem $Y H$, Majd M, Rushton HG, Belman AB. Outcome analysis of pediatric pyeloplasty as a function of patient age, presentation and differential renal function. J Urol 1995;154:1889-1893.

15. Chevalier RL, Thornhill BA, Chang AY. Unilateral ureteral obstruction in neonatal rats leads to renal insufficiency in adulthood. Kidney Int 2000;58:1987-1995.

16. McAleer IM, Kaplan GW. Renal function before and after pyeloplasty: does it improve? J Urol 1999;162:1041-1044. 